\title{
Development of Swimming Sport in Tanjungpinang City
}

\author{
Andri Gemaini ${ }^{*}$, Argantos $^{2}$, and Bafirman ${ }^{3}$ \\ ${ }^{1,2,3}$ Faculty of Sports Sciences, Universitas Negeri Padang, Padang, Indonesia \\ *Corresponding author: Email, andrigemaini@fik.unp.ac.id,
}

\begin{abstract}
This research aims to determine development of swimming sport, that viewed from Coach qualifications, athlete conditions, supporting facilities conditions, and mechanism of swimming sport organizations in Tanjungpinang City, Riau Islands Province. This research is qualitative research, informant from this research is swimming coach, organization committee, and athlete in Tanjungpinang City. Colecting data in this research were obtained by observation, interview, and documentation studies, while secondary data in this research through the document archive data held by swimming management and coach. Others informant will be added with snowball sampling. The result of this research showed that : (1) Qualification of swimming coaches in Tanjungpinang City is good enough and still need attentions, in quality needs to be improved again. (2) Conditions of swimming athletes in Tanjungpinang still not appropriate from ideal. (3) Supporting facilities of swimming sport in Tanjungpinang city looks very inadequate in quality and quantity, and must be managed spesifically (4) Performance of swimming sport organization in Tanjungpinang City is considered to provide support fairly well, while there is still work program that has not done well. It is suggeested to relate parties such as coach, athletes and organization committee to be able to pay attention for this four factors, to be a development of swimming sport in Tanjungpinang City can go according to plan.
\end{abstract}

Keywords: Development, swimming

\section{INTRODUCTION}

Swimming is a sport that is much loved by the public. The existence of swimming in the midst of the rapid development of other sports activities should be a concern of various parties. The reality shows that the achievements of Indonesian swimming athletes have shown increasingly unsatisfactory results. This is one of the effects of the lack of professional coaching for swimming athletes. The same thing happened to swimming sports coaching in the City of Tanjung Pinang, where the declining swimming achievements due to various factors that occur in the coaching constraints. To create athletes with the potential to improve swimming sports achievement, roles and coaching are needed involving various elements including the government, and the participation of the community.

To get potential athletes must start from the search for talent or talent scouting, which starts from coaching at an early age. Specifically, for talent search in the area, it cannot be separated from natural activities or daily activities carried out in the area, natural conditions and in addition to the will or desire of the prospective athlete as well as support from parents is also no less important. Besides these things, also viewed from the seeds of the weight of the prospective athlete, viewed from the physical form and physical health. Physical health of swimming athletes is a body condition related to physical activity and planned systematically that aims and serves to improve individual abilities, physical health and physiological health. After getting an early age athlete who will be trained and fostered, it is necessary to have an appropriate training program from the trainer to improve the ability of the athlete and improve his skills, and the training program must be systematic and structured and assisted with adequate facilities and infrastructure.

Swimming is a body activity carried out in water by moving body parts (legs, hands, and head) so that it produces forward movement. The ability to float the first foundation of a person can swim followed by paddling hands or swimming foot movements does not determine the pattern of movement when it floats and moves from one place to another. But one particular combination of several types of movement can be more efficient than another combination. Furthermore [1] said "swimming provides pleasure, relaxation, challenges, competition and the ability to save lives in emergencies in water". Based on this theory swimming has a variety of benefits for every human being, by swimming can provide its own pleasure resulting in a style of 
swimming is not fast, especially for basic swimming for students who are just learning swimming.

Coaching an athlete is an inseparable part of the organization and coach's efforts in fostering and guiding athletes to improve their abilities and skills. Training and coaching for athletes is carried out with the aim that athletes can achieve the achievements as they expect, this coaching can be done on an ongoing basis. Thus the athletes will achieve more broadly according to the sports that are practiced. [2] argues that "what is meant by the development of sports achievement here is sports coaching conducted with the aim of achieving a sporting achievement". [3] explains the principles of training:

a). The coach should elaborate training objectives together with his athletes.

b). The athlete should actively participate in planning long and short term training programs, as well as analyzing them.

c). The athlete should periodically estabilish and pass tests and standarts. In doing so, one will have a clear picture or the level of performance and degree of improvement in a given period of time.

d). The athlete must undertake individual assignments (home work) and/or individual training sessions without their coach's supervision.

\section{METHODS}

In this research, researchers conducted a qualitative approach using descriptive methods by using observations of natural social phenomena or phenomena.

The research sites are generally carried out in Tanjung Pinang City, and specifically at the training location or at the Dendang Ria swimming pool in Tanjung Pinang City. Then in the office of the PRSI branch manager and the Tanjung Pinang City Swimming Trainer House.

The data in this study are informants, informants are people who know and understand a lot and want to take the time to provide the required data information. Besides they are people who can be trusted. The most important informants in this study were swimming coaches in Tanjung Pinang City, PRSI branch managers in Tanjung Pinang City, and Tanjung Pinang Athletes. Sources of data obtained from these informants.

In this study, the subjects of the research are the trainers, athletes, facilities and infrastructure, as well as swimming sport organizations in the City of Tanjungpinang. Then the initial informant is a swimming trainer and then other informants will be added in accordance with the principle of snowball / Snowball sampling.

To obtain primary data in this study, data collection tools were used in the form of observations and interviews, while the documentation in the form of existing archives was used as supporting data or secondary data. These instruments were used to obtain data about the coaching of swimming sports clubs in Tanjung Pinang.

Data collection in this study was obtained by observation, interview, documentation study and triangulation techniques. While secondary data in this study through the document that is the data archive that is owned by the board, the trainer in the form of a statute and bylaws, training program and notes from the board about swimming sports achievements at Tanjung Pinang PRSI.

\section{RESULT AND DISCUSSION}

\section{A. Result}

In the main facility, which is a swimming pool, Tanjungpinang City Swimming Management still uses privately owned swimming pool facilities, because there are no swimming pool facilities owned by the Tanjungpinang City Government.

\section{Trainer qualifications in coaching swimming sports}

The existence of a coach in swimming sports coaching in the city of Tanjungpinang is in the good category, because the coach has the ability to ingratiate the athlete so that he wants to train seriously and can also motivate the athlete. Thus the trainer has tried to do their performance with awareness to advance the sport of swimming in the City of Tanjung Pinang. the role of the coach is the key to the success of the development and coaching of swimming. The coach is the instructor who directs sports activities to be carried out by the athlete. The better the performance of a coach for his athletes, the better the results will be towards the achievement of swimming in Tanjung Pinang.

\section{The Condition of Athletes in Swimming Sports Coaching.}

The results of research on the state of swimming athletes are still not in accordance with the ideal. If seen from the indicators of the athlete's condition, the athlete still does not have good physical condition and achievement, only the motivation to practice can be said to be good. Tanjungpinang swimming athletes have discipline and seriousness in training, this can be seen in the observations that researchers do, it looks that athletes are enthusiastic in doing training. Various limitations felt by athletes such as the limitations of swimming pool facilities do not dampen the enthusiasm of athletes to practice seriously so that later they can achieve achievements.

Regarding the motivation possessed by swimming athletes in the city of Tanjungpinang, 
researchers also conducted interviews with one of the outstanding athletes in the city of Tanjungpinang

\section{Availability of Swimming Sports Facilities and Infrastructure.}

The availability of swimming sports facilities and infrastructure in Tanjung Pinang City can be said to be very alarming, while the purpose of coaching is to produce talented athletes and produce achievements, it seems as if they cannot be realized. This can be seen when researchers make observations, researchers see the pool used for athletes practicing has a length of 50 meters and 8 tracks, and also the pool looks mossy and the water looks greenish.

Besides that, it was also seen that out of the 8 tracks, swimming athletes in the city of Tanjungpinang were used by only 3 athletes.

The limitations of this swimming pool facility have a very bad impact on the swimming sports coaching process, when the management cannot do much to solve the problems of these facilities and infrastructure, if not resolved as soon as possible, it will certainly have a negative impact on athletes

\section{The Role of Organizations in Swimming Sports Development.}

In the swimming sport branch which is the organization of the parent organization is the AllIndonesian Swimming Association or abbreviated as PRSI. The role of this organization is needed in the implementation of swimming sports development, especially in the City of Tanjungpinang.

In a sports organization so that it can run well and smoothly there must be a partnership between the government and the private sector. The collaboration is highly expected to be a moral and material support for the organization in carrying out sports coaching. When conducting an interview with the Tanjung Pinang PRSI Pengcab management, the researcher asked the management about the tasks and functions as well as the work program.

The obstacle felt by the athlete is very unfortunate because athletes who already have good abilities must also often take part in competitions outside the region so that athletes can know their abilities and later to be improved again, so the athlete's achievements are not only limited to the region. The interference of government officials in handling sports performance improvement would have a good impact on sports coaching in an area.

From the above opinion it can be concluded that there is a need for good cooperation from various parties so that what is expected and the goals of the organization will be realized as desired.

\section{B. Discussion}

The existence of a coach in swimming sports coaching in the city of Tanjungpinang is in the good category, because the coach has the ability to ingratiate the athlete so that he wants to train seriously and can also motivate the athlete. Thus the trainer has tried to work to do their performance with awareness to advance swimming in Tanjung Pinang City. the role of the coach is the key to the success of the development and coaching of swimming. The coach is the instructor who directs sports activities to be carried out by the athlete. The better the performance of a coach for his athletes, the better the results will be towards the achievement of swimming in Tanjung Pinang.

Substantially a coach is a person who has professional abilities that can provide information, experience and skills needed by an athlete. It is not possible for a coach to give birth to a talented athlete, if he does not have the knowledge and experience of coaching. This coaching science has elements that are quite complete and can be applied into interesting and objective activities.

a demanded coach must have a desire to learn and a desire to get a better level of coaching, so that later they are able to facilitate the process of sports coaching in their respective regions. But in this case it is still not enough, a coach must also have a sense of discipline and high responsibility with what he aspires with athletes. Discipline and responsibility are one of the powerful tools to bring athletes to a higher level, and from this there will be an increase in better social relations that will indirectly be able to help and provide positive value in the coaching process.

Athletes are both objects and subjects in coaching. The success of the coaching process in achieving goals, much depends on the potential of the athlete and the ability of the coaching to awaken that potential. Therefore, a) the process of scouting talent, b) determining the appropriate branch or number for a prospective athlete, c) coaching based on a strong national ideology and integrated with a pedagogical approach, and d) career guidance in the future is a factor it is important to note that coaching is achieved.

Athletes will be able to excel if taken seriously in accordance with their talents. An athlete who has good talents will enter into sports achievements, but for athletes who have less talent for sports, then he will make sports as recreational sports or sports for health and will not pay too much attention to his achievements. This condition must actually be done by an objective trainer, so that the coaching can be directed, namely through "talent scouting" or the selection of talented athletes. 
To choose this talented athlete does require several criteria, among others, besides having a good physique, he also has a good mental attitude that is having a sense of responsibility, cooperation, high discipline, and a positive attitude towards things that come from outside, and have commitment in practice. So that all these components can be put together so as to produce an intact ability as a good athlete.

Tanjungpinang City swimming athletes who are still being trained by Tanjungpinang City swimming coaches are 15 athletes consisting of 7 boys and 8 girls, they practice together. The possible drawbacks that occur in swimming athletes in Tanjungpinang City, are the average physical and technical factors, while from a mental standpoint it seems that it is sufficient to just live how to increase the desire to excel, and this needs to be trained continuously, so that with the potential it has athletes will be able to develop and will be able to improve athlete achievement.

Besides that their motivation to practice is good enough, it's just that the motivation needs to be maintained and also needs to be improved given the many obstacles they have encountered. High motivation will help athletes to achieve achievements, because if athletes have good physical and technical skills but are not added with high motivation, achievement will never be achieved, because motivation also has a very important role from the training process to finally achieving achievement. Achievement motivation is motivating someone who has the desire to strive for success and choose success-oriented activities.

Sports facilities such as swimming pool facilities are a very important element in the swimming sports coaching process. To carry out good coaching activities in the environment by the community such as in recreational sports activities, there is still a strong tendency that facilities that meet needs are far from adequate. The ideal swimming pool is to have a length of 50 meters with 10 lines, then a 2.5 meter wide line and a depth of 2 meters for the National, 3 meters for International, besides the pool water temperature must be adjusted to 25 to 28 degrees Celsius and the lighting is 1500 lumens so that athletes who practice do not feel cold when practicing in winter. Swimming pool facilities become the main cause of the inhibition of swimming sports development in Tanjung Pinang City, this also makes athletes feel disturbed to practice, athletes become difficult to develop their potential, as a result of these limitations it makes athletes carry out additional training on their own without being trained by the coach in order maintain performance. Without adequate facilities and infrastructure, it will be difficult to improve swimming sports achievements in Tanjung Pinang City.
Organizational management is one element that cannot be ignored. The success of a particular sport is very dependent on the management of the organization. If the management of the organization has high loyalty with the meaning of being willing and able to manage the mechanism of each work with a full sense of responsibility, rest assured that what is done by a coach and athlete in the field will be able to achieve better results. Professional attitude and supported by good cooperation will have an impact on the coaching of certain sports. Administrators must have a clear work program, especially programs related to coaching, this program must be run and not just have as a concept. This funding issue is also an obstacle in the development of swimming in Tanjung Pinang City. not all Management of swimming organizations that have independence in running the organization. With these conditions the management must work hard to mobilize people and the private sector in order to help with the costs of developing and operating the organization. Management is required to be able to solve problems such as pool rental contracts. We realize that swimming managers in the City of Tanjungpinang are people who have the desire to advance the sport of swimming in the City of Tanjungpinang. so it is very natural that this severe problem can be done by an administrator to be able to provide the best for the progress of swimming sports coaching.

The most expensive cost for administrators is to finance athletes in participating in competitions outside the region and to hold races. Support through other parties is still not optimal, despite having a good cooperative relationship. But to provide financial assistance still feels very difficult. Therefore, it is necessary to approach or other ways that might be more effective to assist the board in moving this organization. This is where understanding and sacrifice is needed from all parties, including the management, to be able to understand that to get achievements does require large funds. An effective way is to optimize cooperation with other parties, especially Indonesian Sport Commitee, the private sector, related institutions and also parents, so that later administrators can easily run the organization. It is impossible that all these needs are only left to the management, all of them must share responsibility, if you want to get good achievements, including holding competitions both regional and national, productive breakthroughs need to be made.

\section{CONCLUSION}

By looking at the descriptions of the previous chapter, some conclusions can be drawn that are abstractions of the entire contents of this study. Therefore, a conclusion can be drawn that generally can 
describe swimming sports coaching in Tanjung Pinang City, and this research can be summarized as follows:

1. Tanjungpinang City swimming coach qualifications still need to be considered, the quality needs to be further improved, especially relating to the preparation of a good training program and its application to athletes. Then the coach also needs to further enhance his creativity in training so that the trained athlete does not feel bored and bored, so that coaching becomes more effective.

2. The state of Tanjungpinang swimming athletes is still not in accordance with the ideal, the athlete's motivation can be said to be good. But it also needs to improve the training system, knowledge and increase the number of competitions both in the region and outside the region. Because these factors are still not optimal in supporting swimming sports coaching in Tanjung Pinang City. Besides that, there are still many talented athletes who have not been touched effectively, in coaching or funding, so they lack the opportunity to practice and participate in competitions outside the region.

3. Swimming sports facilities and infrastructure in the city of Tanjungpinang look very inadequate and there needs to be serious attention, because the pool is not in accordance with the standards, and the lack of management of the pool makes the swimming pool training in the City of Tanjungpinang hampered. The pool facilities managed by the private sector also provide less assistance and relief related to pool rental. The limited relationship between the government and the management and the pool manager also makes swimming sports training hampered.

4. The role of swimming organizations in the Tanjungpinang City is considered to have provided quite good support. Although there are still work programs that are well implemented. Then the attitude and program issues need to be improved, so that the coaching process can go well. The main focus is to give athletes a lot of experience and improve their achievements, through the management program and at the same time their professional attitude. With high independence the management has tried as much as possible to do their best, but maybe the ability of the regions or related institutions is very limited, so the results of collaboration carried out by the management of these parties also experience obstacles. Besides that, the realization of the program is possible to influence the development of swimming sports, especially those related to race programs or events that are still constrained. Competitions must often be made and carried out by involving all groups on a regular and planned basis.

\section{REFERENCES}

[1] Thomas. David G. (2006). Advanced Level Swimming. Jakarta. Raja Grafindo Persada

[2] Syafruddin (1996). Fundamentals of Training. Padang: FIK UNP

[3] Bompa, Tudor. (1990). Theory and Methodology of Training. Amerika : Kendall/ hunt publishing company.

[4] Dartija, Dadi. Thesis. Analysis of Swimming Athlete Training in Provincial Administrators and Branch Managers of the Indonesian Swimming Unity (PRSI) in Aceh in 2013.

[5] Emral. (2000). Sports Coaching Science. Padang: UNP Press.

[6] Fardi, Adnan. (2007). Development of Athlete Motivation Instruments. Malang: Wineka Media.

[7] Iskandar. (2008). Educational and Social Research Methodology. Jakarta: GP Press

[8] Maglischo Ernest W. (1993). Swimming Even Faster. Amerika: California State University

[9] Moleong, Lexy J. (2000). Qualitative Research Methodology. Bandung: Remaja Rosda Karya.

[10] Sanapiah, Faisal. (1990). Qualitative Research, Basics and Applications. Malang: IKIP Malang.

[11] Setyobroto, Sudibyo. (1993). Coaching Psychology. Jakarta. CV. Jaya Sakti.

[12] Sugiyono (2012). Quantitative, Qualitative, and R\&D Research Methodologies. Bandung: Alfabeta. 